\title{
THE CHARACTERISTICS OF BEAM STRING SYSTEMS
}

\author{
Margaréta KUSENDOVÁ ${ }^{1}$, Tomáš KLAS ${ }^{1 *}$
}

\section{Abstract}

Large-span constructions are used more and more today in practice. While concrete and steel previously played a leading role, now constructions which use wood as a building material occur more often. This article deals with problems related to composite structure made from steel and wood by focusing on the connections of these structures in more detail. The main part of this work concentrates on the experimental verification of the resistance of four types of joints. It compares the results with Eurocode 5: design of timber structures.

\section{Address}

1 Department of Steel and Timber Structures, Faculty of Civil Engineering, Slovak University of Technology, Radlinskeho 11, 81368 Bratislava, Slovakia

*Corresponding author: tomas.klas@stuba.sk

\section{Key words}

- Experimental verification,

- joint,

- screws to wood.

\section{INTRODUCTION}

Large-span constructions are used more and more today in practice. While concrete and steel previously played a leading role, now constructions which use wood as a building material occur more often. Wood is used on many occasions in combination with the above-mentioned materials. It is usable for building light roof constructions, halls for sports and agricultural purposes, foot bridges and cyclist bridges, assembly of houses, multi-floor buildings (residential dwellings, administrative buildings, schools, etc.) and other special buildings (churches, representative buildings, etc.) and auxiliary constructions. This work will deal with problems related to combining constructions made from steel and wood by focusing on these constructions in more detail.

\section{ANALYSIS OF THE JOINTS OF HYBRID-BEARING SYSTEMS}

Recently, the construction industry has paid increased attention to structures and their connections, combined with a focus on beam string structures. The most common structures are social, cultural, sports and industrial buildings. Interesting historical, as well as contemporary wooden constructions, also seem to be the focus of attention.
The following aspects are described:

1. Theoretical tasks related to the beam string structures of steel and wood and the use of beam string structural material for construction.

2. A characterization of the means investigated to connect various elements to the main backbone element and a proposal concerning the basic geometry of the selected connections.

3. A definition and assessment of the geometry of the selected services for the preparation of the experiment. The design of the experiment, the choice of the appropriate measurement method, and the choice of instruments for the chosen method of measurement.

4. The verification and comparison of the theoretical and experimental designs of the resilience of the connections. Processing of the graphic and tabular results.

5. The verification and comparison of the results.

A beam string structure system consists of three basic load-bearing elements. The first one is a flexible stiffening solid-beam element which mainly carries the compression and bending moments. The main difference between beam string structures and truss structures is that the flange elements of truss systems in most cases carry axial forces. The second essential element of beam string structures is the strut (or struts) - pliable supporting elements which reduce the span of the stiffening beam. These usually carry buckling compressive 
forces. The third element is the drawbar, which carries the tensile forces. The creation of a pair of forces on a fictitious arm with the compressive forces in the stiffening beam helps the system withstand the effects of outer bending moments.

The basic types of groups are triangular, trapezoidal, and polygonal systems of flat beam strings and parallel beam strings. The second group we can classify as a spatial system is a beam string structure, which is largely derived from the basic flat beam string structure systems or their modification in combination with other key systems. Beam string structure systems are effective for a larger margin and at the same time satisfy aesthetic requirements. We focused on the design, where the main supporting element of the glued wood rectangular cross section was designed using slat struts and originated in closed steel circular profiles. The analysis of a planar beam string structure from a static point of view compares the four basic beam string structure systems (triangular, trapezoidal, polygonal and parallel beam strings) to girders and planes. The main support in all the cases was designed as a rectangular cross-section of the GL24h glued slat timber and struts and tension elements from S235 steel. The margin was considered as $15 \mathrm{~m}$ with the width of the loaded structures as $1.5 \mathrm{~m}$.

All the constructions were consistently loaded with a constant load of $0.75 \mathrm{kN} / \mathrm{m}^{2}$ and load variables - snow of $1.05 \mathrm{kN} / \mathrm{m}^{2}$ (II. snow area). The calculations also included the weight of the structure itself. The static calculations, by means of the IDA Nexis computational program, identified the distribution of the internal forces $(\mathrm{M}, \mathrm{N})$ and deformations on the main spar. The calculations were performed on a beam with a buckling reinforcement. The deflection limit was intended in all the cases to be on a $1 / 350$ scale.

All the designs were dimensioned in terms of compliance with the requirements for the condition of the ultimate limit states and the limit state of the serviceability limit states. In the calculations of the deflection with creeping in the limit condition of excellent, usage class 1 for glued laminated timber was considered. The value of the coefficient of $\mathrm{k}_{\text {def }}$ equals 0.6 for this class. For the calculation of the deflection, the following equation according to STN EN 19951-1 was used:

$$
u_{\text {fin }}=u_{\text {inst }}\left(1+k_{\text {def }}\right)
$$

We found that with the addition of a number of rods due to the sheer spar, we increased the effectiveness from a static point of view and also from the gauge; thus the material consumption is shrinking. The progression of the bending moments can be decreased by $4-43 \%$ (compared to the sheer truss) through selecting the appropriate type of beam string structure. Furthermore, the distribution of the bending moments is very favourable for polygonal string structures, thus leading to satisfactory material consumption and reasonable displacements.
The experimental research was carried out in the laboratory of the Department of Steel and Timber Structures. The focus of the experiment was on three types of simple connections, which deal with the connection of steel pushrods to the timber element of the beam. The theoretical calculation of each connection was compared to the standard for the design of timber structures (EN 1995-1-1).

\subsection{Types of joints, material and geometry}

The preparation of the experiment consisted of three parts. The first part focused on a proposal for all the various types of joints of a combined beam of steel and wood. The first task was sizing the simple triangular beam string structure with a margin of 9 meters. The design of the connections was based on the course of the axial forces on the following proposed beam string structure.

The overall load was composed of a self-weight permanent load (from a roof of $0.75 \mathrm{kN} / \mathrm{m}^{2}$ ) and a snow load (II. snow area). The height of the beam string structure was 1.7 meters. The rectangular cross section with dimensions of $160 \times 220 \mathrm{~mm}$ was made of a GL24h glued wood slat; the strut section was $38 \times 4 \mathrm{~mm}$ and $\Phi 35 \mathrm{~mm}$. Both were made of S235class steel. The IDA Nexis FEM based software was used for the calculations.

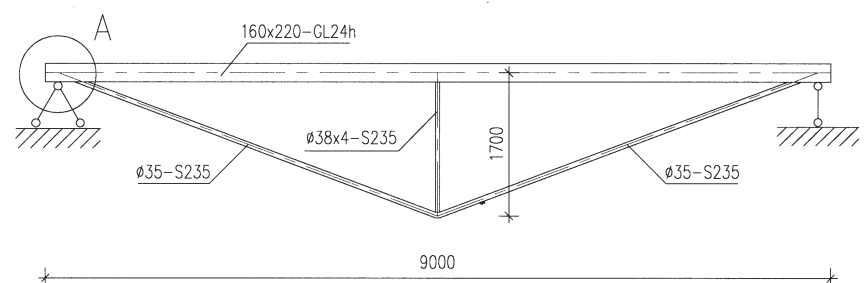

Fig. 1 Triangular beam string.

For the design of large-span structures, it is possible that incorporating jacking steel handles could slightly influence the timber beam. Jacking would mainly be advantageous for assessing the yield condition of availability. Allowing displacement in our case would not play any considerable role, since it would cause a reduction of the distortions without any impact on the cross section. For this reason, the calculations were made on a simple triangular beam string without considering the action of jacking steel handles.

The second part dealt with the detail of the abutment of a steel handle beam to the timber at the point of the supporting leg. Several variants of connections were proposed. In the context of the experimental measurements, four possible ways to connect the wire handle

Tab. 1 Static analysis of a planar beam string.

\begin{tabular}{|l|c|c|c|c|c|c|}
\hline TYPE & $\begin{array}{c}\text { THE MAIN } \\
\text { GIRDER } \\
(\mathbf{m m})\end{array}$ & $\begin{array}{c}\text { NORMAL } \\
\text { VOLTAGE } \\
\text { “M” (MPa) }\end{array}$ & $\begin{array}{c}\text { NORMAL } \\
\text { VOLTAGE } \\
\text { “N”(MPa) }\end{array}$ & $\begin{array}{c}\text { THE TOTAL } \\
\text { VOLTAGE } \\
\text { (MPa) }\end{array}$ & $\begin{array}{c}\text { DEFECTION } \\
\text { (mm) }\end{array}$ & $\begin{array}{c}\text { DEFLECTION } \\
\text { WITH } \\
\text { CREEPING (mm) }\end{array}$ \\
\hline SIMPLE BEAM & $180 \times 750$ & 7.638 & & 7.638 & 30.595 & 48.592 \\
\hline TRIANGULAR BEAM STRING & $180 \times 400$ & 4.942 & 1.417 & 6.359 & 10.711 & 17.138 \\
\hline TRAPEZODIAL BEAM STRING & $180 \times 300$ & 3.162 & 1.498 & 4.660 & 6.116 & 9.786 \\
\hline POLYGONÁL BEAM STRING & $180 \times 260$ & 2.523 & 1.749 & 4.272 & 5.890 & 9.424 \\
\hline PARALLEL BEAM STRING & $180 \times 500$ & 4.458 & 0.638 & 5.096 & 8.461 & 13.538 \\
\hline
\end{tabular}


Tab. 2 Distribution of the test samples.

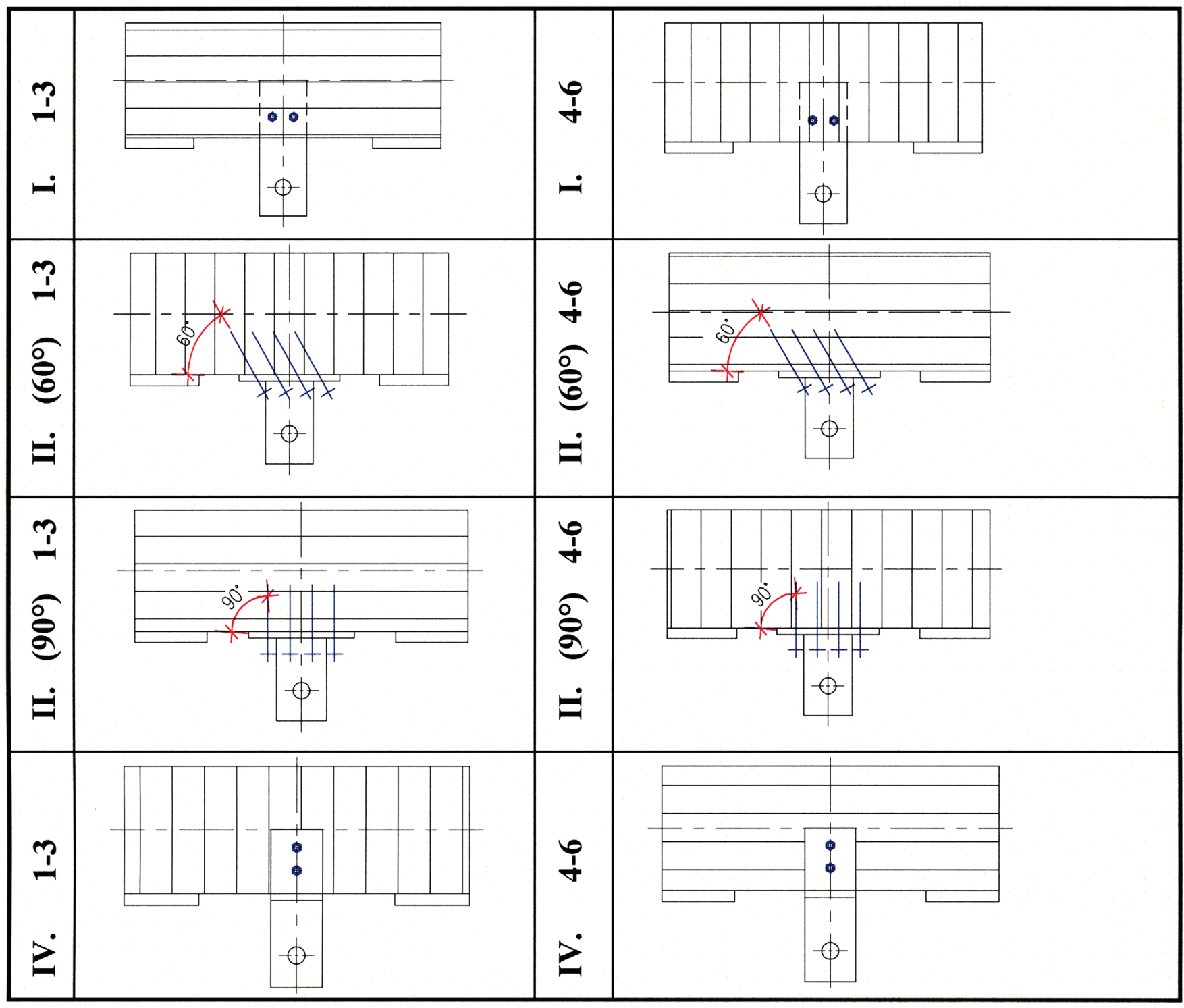

were assessed, all of which were adapted and simplified to meet the needs of the experimental verification.

The first connection method was implemented through an embedded steel plate with the dimensions of $90 \times 260 \mathrm{~mm}$ and a thickness of $12 \mathrm{~mm}$, which was retrofitted with steel threaded rods of the strength class 8.8 with a $10 \mathrm{~mm}$ diameter. The second way of connecting was designed with the help of wood screws. For the purposes of the experimental measurements, we used ordinary wood screws with a partial thread (Hexagon screw strength class 4.6). The wood screws were inserted on a welded steel plate with a thickness of $12 \mathrm{~mm}$ in the shape of a $\mathrm{T}$ with 8 pieces of a $8 \mathrm{~mm}$ diameter. This joint tested two connection methods. The first way was when the wood screws were applied at a $60^{\circ}$ angle; while in the second case, the angle between the slats and couplings was $90^{\circ}$. The cross section of the truss and material was the same as in the first case, i.e., a rectangular cross section with measurements of $160 \times 220 \mathrm{~mm}$ made of glued wood.

The third connection method was implemented using the "steel" to shape "the forks" of the welded slippers; a steel sheet with a thickness of $12 \mathrm{~mm}$ and steel rods with a diameter of $10 \mathrm{~mm}$ from strength class 8.8 were attached to the timber beam element. Wooden beams made of glued wood were used, with dimensions of $160 \times 220 \mathrm{~mm}$ and a length of 600 and $900 \mathrm{~mm}$.
In all the cases, rods were used with matching washers and nuts. Threaded rod bolts, which should have been a substitute for such types of connections, were used. In practice, a threaded rod would be used in most cases, and for this reason the actual conditions were simulated as precisely as possible in the experiment. The charging scheme and loading method were the same in all the cases.

\subsection{Measuring equipment}

The experiment was carried out in the Laboratory of Measuring Equipment of the Department of Metal and Wooden Structures. For the implementation of the experiment, the measuring equipment of the department was used. The entire experiment was transferred to the ZD 100 (producer of Leipzig 1966 WPM) stationary hydraulic press brake with a maximum loaded force of $1000 \mathrm{kN}$. The press was provided with a steel structure, which served to hold the test samples. The steel frame was welded from a sheet with a thickness of $15 \mathrm{~mm}$ and COUNTY 260 profiles. As a support for the test samples, the COUNTY 260 profiles were used, one of which was a fixed prop (welded) and the other removable (fixed with $2+2$ bolts of the M12-strength class 8.8 ), due to the possibility of an exchange of the samples and the need to repeat the experiment 
For the measurements, a SPIDER 8 apparatus from HBM was used. The device, which was connected to the PC, recorded and processed the measured data by means of CATMAN software. The recording was set at a $2 \mathrm{~Hz}$ range. The values measured were saved in Microsoft Office Excel in a tabular format and successively processed graphically. The samples were loaded with a tensile force, the value of which was measured using a C6A/MN sensor pull. Part of the power meter also included a special joint in order to ensure a uniform application of the force, which was divided between the power meter and the steel frame. Prior to the testing, each of the samples was measured to record its basic dimensions, humidity and temperature as well as the humidity and temperature of the environment.

\subsection{The progress of the loading}

Twenty-four samples were tested in the course of the experiment The test samples were divided into groups according to the orientation of the slats due to a coupling agent and according to the type of connection. Eight groups were determined, each of which contained three representative samples. The Roman number represents the type of sample and the Greek number defines the orientation of the sample on the basis of the slats. An overview of the groups and representative samples of the test is demonstrated in Table 2.

The choice of a vertical orientation of the slats in the direction of the application of the force was exclusively chosen for the experimental tests. The aim was to determine and compare the results of this proposed merge with the theoretical values. The samples were loaded with an axial tensile force. Based on the standard STN EN 380 , load cycles were chosen for all the groups (load-constant level of load-relieving), which are defined in the various chapters dealing with the groups. The progress of the loading consisted of progressive loading and load decreasing samples for each value.

\subsection{The progress and evaluation of the experimental measurements for group I.}

Each group of samples was preceded by a test of the prototype of the given group. It served to determine the behavior of the sample as a whole and also to eliminate any deficiencies and define the individual ballast degrees. The measurements took place in places parallel to the fibres, perpendicular to the fibers, and fibers perpendicular to the radial tangentially. The test report from the laboratory and a picture of an intact sample are shown in Figure 2.

With this type of connection and orientation of the slats, horizontal cracks appeared around the fasteners (Fig. 3-the first cracks), which became bigger as the load increased. By increasing the bending load in the fasteners, a bruising of the shims appeared, which led to a zip-line effect (Fig. 4). Infringement occurred in the fibres.

\subsection{The progress and evaluation of the experimental measurements combined in group II. $\left(60^{\circ}\right)$}

The second experimental group used wood screws as the connection elements. Standard STN EN 1995-1-1 defines the angle between the fibres and the couplings for the design of this type of fastener. For the experimental verification tests, two methods were adopted for the wood screws. In the first case, the wood screws were at an angle of $60^{\circ}$, while in the second case the angle was $90^{\circ}$. Such a symbol is also used in the following pictures and tables. We used $\phi 8 \mathrm{~mm}$ wood

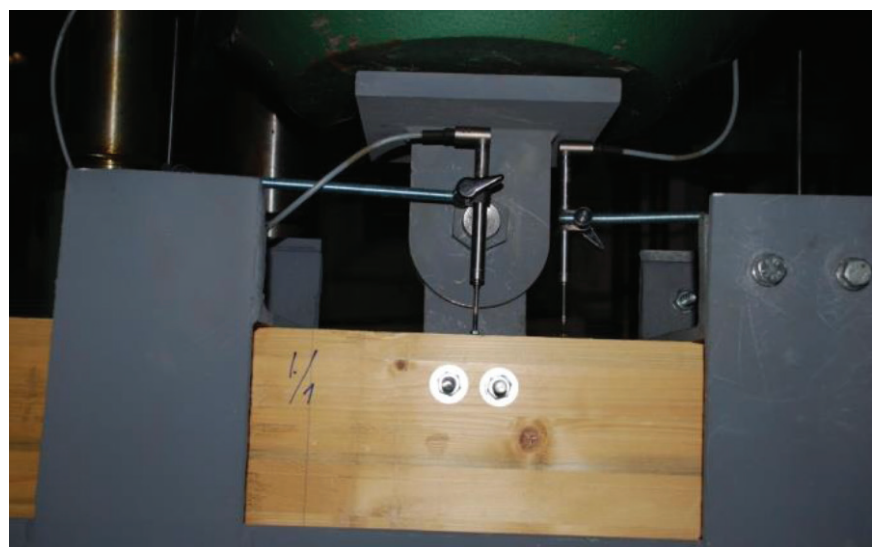

Fig. 2 The intact specimen.

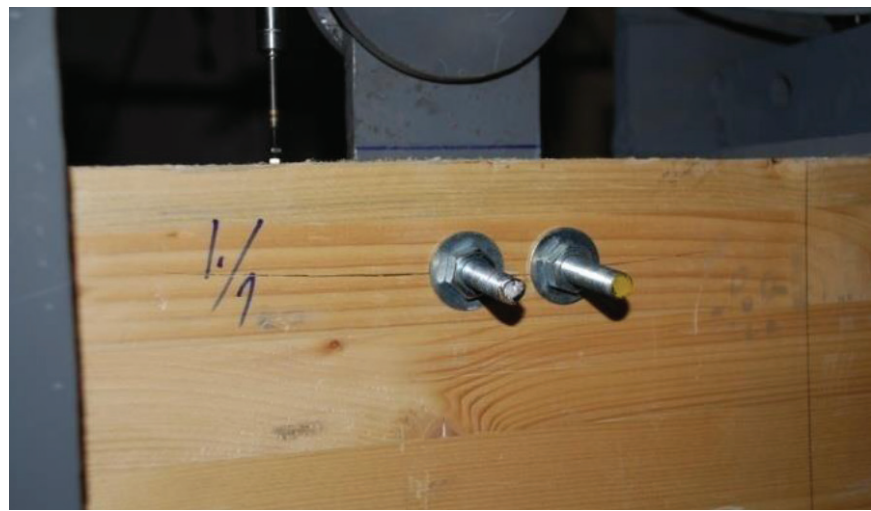

Fig. 3 The first crack of the wood.

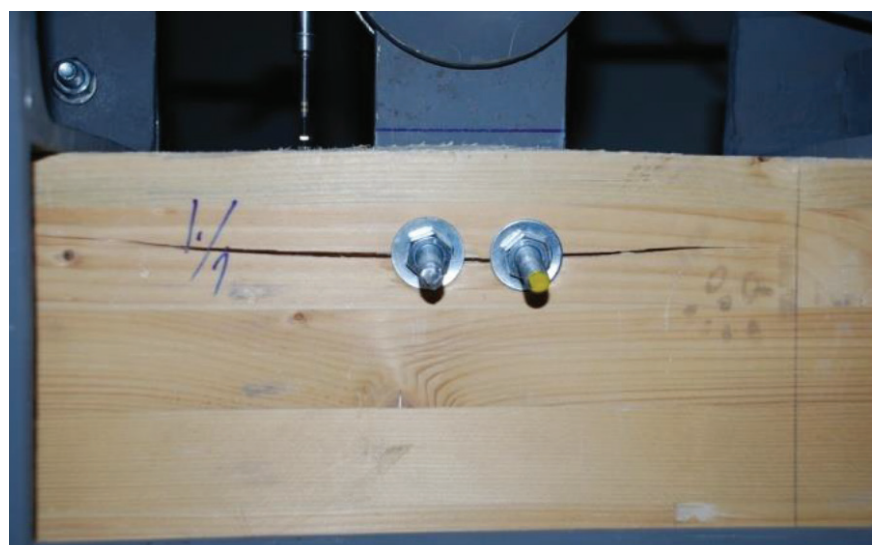

Fig. 4 The opening of the cracks.

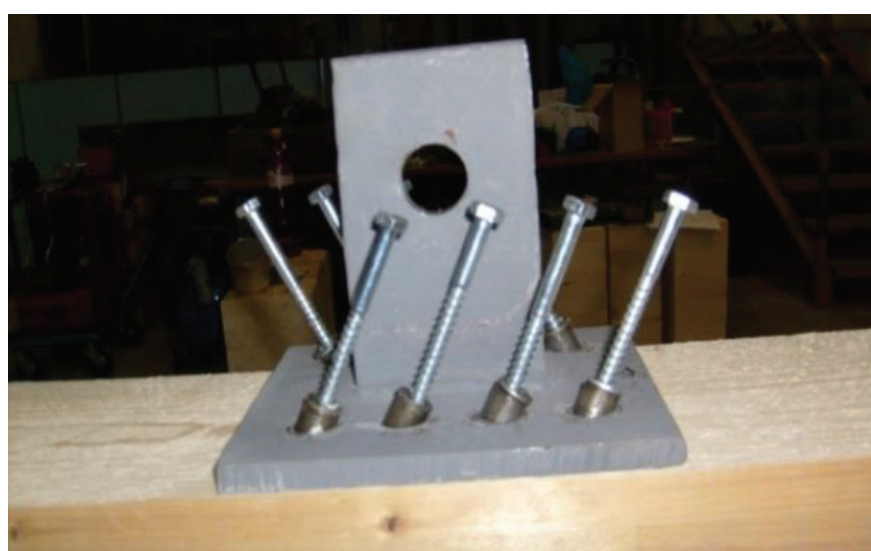

Fig. 5 The application of the screws to the wood. 


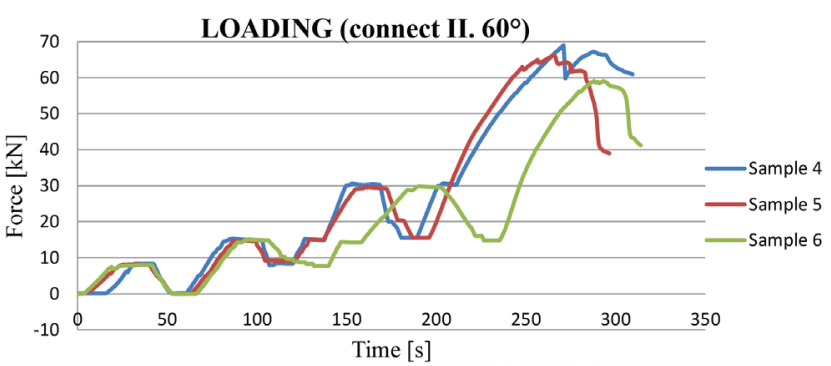

Fig. 6 Method of loading samples 4-6.

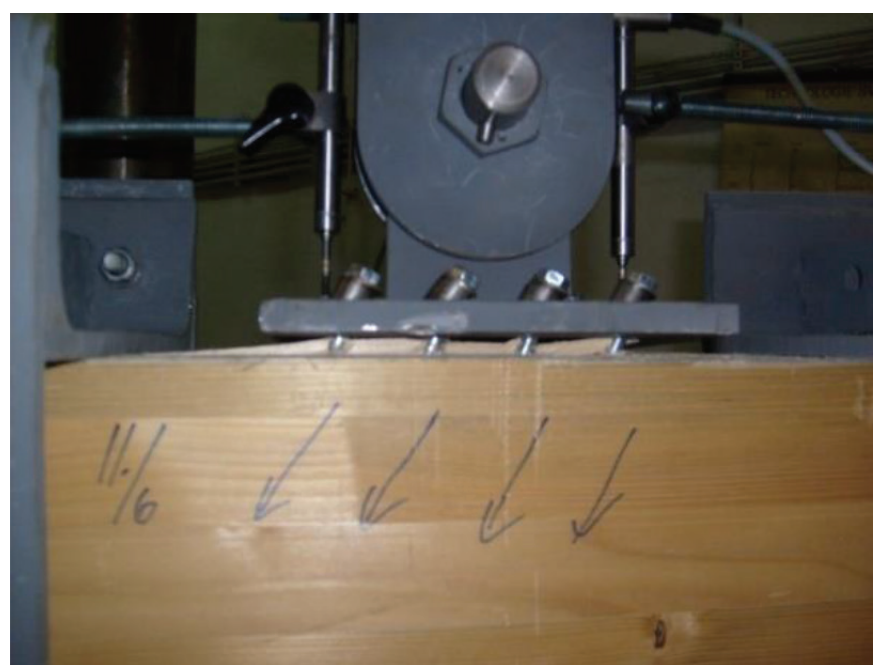

Fig. 7 Violation of the sample.

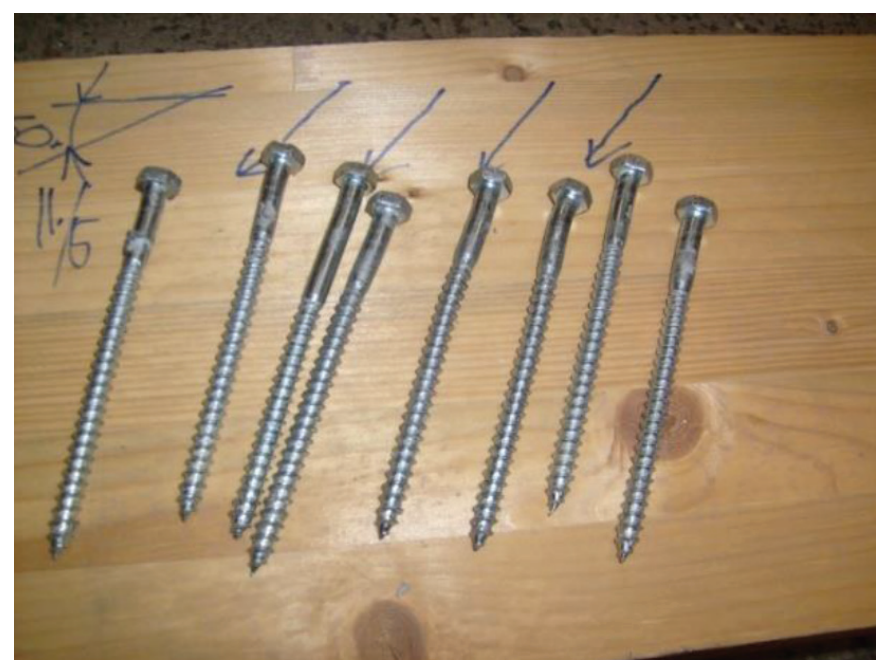

Fig. 8 Deformed fasteners.

LOADING (connect II. 90)

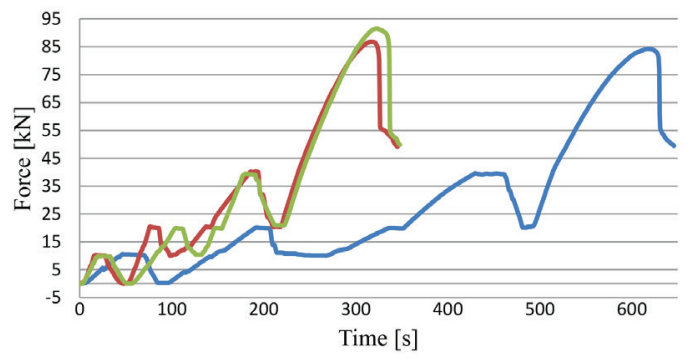

Fig. 9 Method of loading samples 1-3. screws with a partial thread, which were mounted into holes drilled in advance in two directions (Fig. 5). The design resistance of the connection with wood screws at a $60^{\circ}$ angle according to the standard was $28.75 \mathrm{kN}$. For loading the samples after testing a prototype of this group, the chosen load levels were $7.5 \mathrm{kN}$ and $15 \mathrm{kN}$ with a ballast of $30 \mathrm{kN}$. The resistance of this group went beyond the norm set by the resistance, which is obvious from Figure 6. The order of magnitude ranged around $60 \mathrm{kN}$.

In the case of this group, the fasteners were pulled out unilaterally. This may have been a twist that caused strains that may have resulted in the splitting of the material. The wood screws were slightly deformed, but the structure did not collapse, as can be seen in Figures 7 and 8 .

\subsection{The progress and evaluation of the measurements combined for group II. $\left(90^{\circ}\right)$}

A similar procedure was used for the samples. In this group, the angle between the wood and screws was $90^{\circ}$. The principal and stocking screws were similar to the screws for the wood below a $60^{\circ}$ angle. Screws of the same diameter as the previous type were used together and were mounted into holes drilled in advance.

The design resistance of the joints connecting the steel plate by means of the screws for the wood at an angle of $90^{\circ}$ was calculated, and its value was $27.11 \mathrm{kN}$. The load was applied in cycles, with increasing values of $10 \mathrm{kN}, 20 \mathrm{kN}$, and $40 \mathrm{kN}$. The loading is shown graphically in Figure 9.

The progress of the deformations and their maximum value in the previous case are shown in Figure 10. There was no breach of the whole sample; only the screws and steel plate were pulled out unevenly. The deflection of the fasteners was either none or only minimal. The maximum value of the resistance obtained from the experimental verification was higher than the theoretical resistance, and the circuit board remained intact.

\subsection{The progress and evaluation of the experimental measurements for Group IV.}

In Group IV, the connection of the steel pushrods to the timber element consisted of steel plates from the outer side, two bolts and screws (in our case, threaded rods). As in all the previous cases, threaded rods with a diameter of $10 \mathrm{~mm}$ were used and were mounted into holes with $10 \mathrm{~mm}$ diameters. For Group IV, the design bearing capacity was calculated.

For samples with a horizontal slat position, the value of the resistance obtained from the experiment was considerably high.

THE PROGRESS OF THE DEFORMATIONS (connect II. 60 ${ }^{\circ}$ )

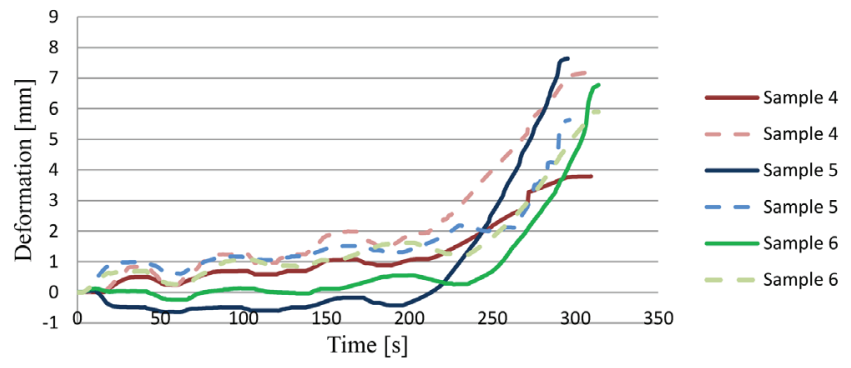

Fig. 10 Course of the deformations of samples 1-3. 


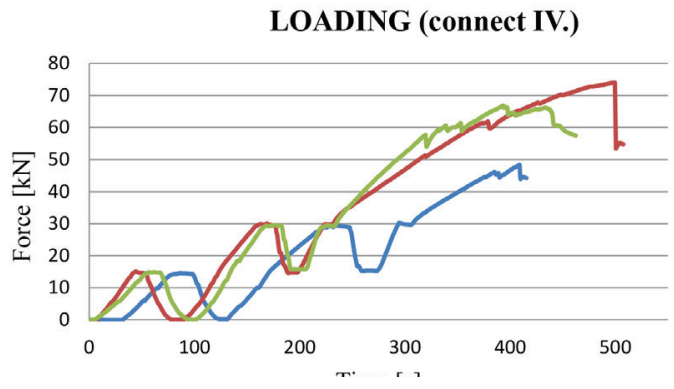

Fig. 11 Method of loading samples 4-6.

THE PROGRESS OF THE DEFORMATIONS

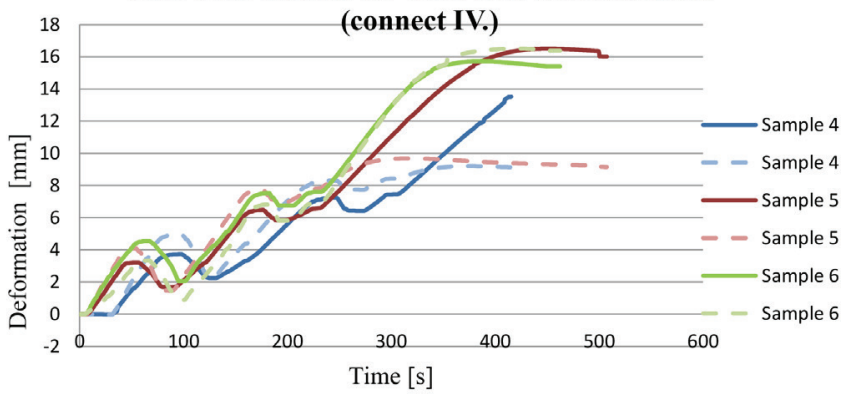

Fig. 12 Course of the deformations of samples 4-6.

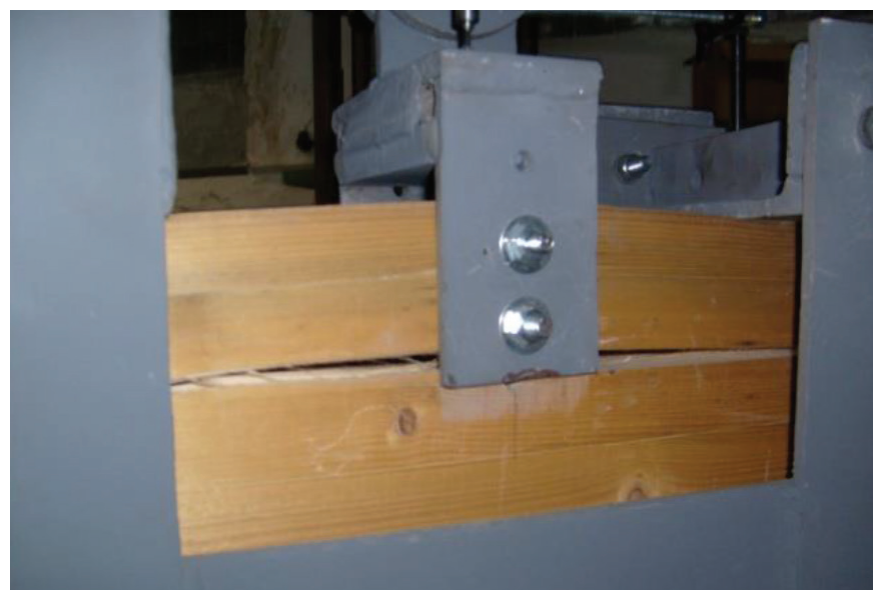

Fig. 13 Violated sample IV/5.

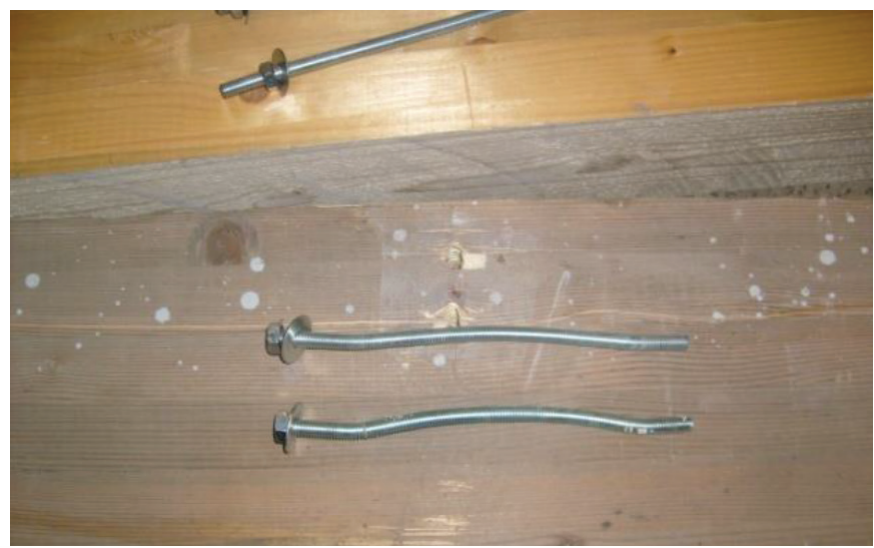

Fig. 14 Deformed fasteners.
Samples 4-6 showed, as in all the cases, a rupture of the wooden element. Horizontal cracks appeared around the fasteners and split open as the load increased, leading to deflection of the pads and bending of the rods. A collapse of the fasteners did not take place. The decisive mechanism of failure according to standard STN EN 19951-1 was the mechanism of "l". The connection failed due to a lack of tensile strength perpendicular to the fibers of the wooden beam.

\section{SUMMARY AND COMPARISON}

The experiment was focused on connecting a steel handle to a timber beam. The selected geometry was assessed by calculating the theoretical design of the connections according to Eurocode 5: design of timber structures. The aim was to identify the actual design of the experimental measurements of the resistance and then make a subsequent comparison with the theoretical resistance.

For the experimental verification, glued lamellar wood joints were chosen as the material. All the strength and material characteristics used in the calculations were equal to the characteristics and strength of the glued laminated timber class GL24h. Due to the time schedule no samples were subjected to tensile tests to determine the characteristics of their rigidity. The design of the geometric calculations and measurements considered the fact that the strength of timber depends on the angle between the fibres and the load applied, the moisture and the duration of the load. As the strength of both the sawn timber and glued wood reaches their highest value in a direction parallel to the fibers, the laboratory tests were designed to verify the tensile strength perpendicular to the fibers.

In the context of the experiment, two types of slat orientations were examined - the horizontal orientation of the slats and the vertical orientation, which can be defined as the force exerted perpendicularly on the fibers. It should be stressed that a case of the vertical orientation of the slats will not occur in practice. The selected orientation of the slats was applied only to the experimental measurements. For a simplification of the measuring conditions, the same degree of the load was applied to the sample for the horizontal slats as to the sample for the vertical slats.

From Table 3., it is clear that the beams with a horizontal orientation of the slats had a greater resistance than the expected design resistance obtained by the calculations. In the table, those values are marked in green, and the resistance was achieved in all cases. 
Tab. 3 Summary and comparison.

\begin{tabular}{|c|c|c|c|c|c|c|}
\hline \multirow{3}{*}{$\begin{array}{c}\text { TYPE OF } \\
\text { COUPLING }\end{array}$} & \multicolumn{6}{|c|}{ DESIGN RESISTANCE [kN] } \\
\hline & STN EN 1995-1-1 & EXPERIMENT & \multirow{2}{*}{$\Delta 1$} & $\begin{array}{l}\text { STN EN } \\
1995-1-1\end{array}$ & $\begin{array}{l}\text { EXPERI- } \\
\text { MENT }\end{array}$ & \multirow{2}{*}{$\Delta 2$} \\
\hline & $\begin{array}{c}\text { THE HORIZONTAL } \\
\text { SLATS }\end{array}$ & $\begin{array}{c}\text { THE HORIZONTAL } \\
\text { SLATS }\end{array}$ & & $\begin{array}{l}\text { VERTICAL } \\
\text { SLATS }\end{array}$ & $\begin{array}{l}\text { VERTICAL } \\
\text { SLATS }\end{array}$ & \\
\hline \multirow{3}{*}{ I. } & \multirow{3}{*}{23.01} & 28.92 & $25.68 \%$ & \multirow{3}{*}{23.01} & 9.48 & $41.20 \%$ \\
\hline & & 25.80 & $12.13 \%$ & & 11.76 & $51.11 \%$ \\
\hline & & 30.42 & $32.20 \%$ & & 9.12 & $39.63 \%$ \\
\hline \multirow{3}{*}{ II. $\left(60^{\circ}\right)$} & \multirow{3}{*}{28.75} & 68.94 & $139.79 \%$ & \multirow{3}{*}{28.75} & 38.88 & $35.23 \%$ \\
\hline & & 66.18 & $130.19 \%$ & & 30.42 & $5.81 \%$ \\
\hline & & 59.04 & $105.36 \%$ & & 31.62 & $9.98 \%$ \\
\hline \multirow{3}{*}{ II. $\left(90^{\circ}\right)$} & \multirow{3}{*}{27.11} & 84.24 & $210.84 \%$ & \multirow{3}{*}{27.11} & 37.2 & $37.22 \%$ \\
\hline & & 86.82 & $220.25 \%$ & & 26.88 & $99.15 \%$ \\
\hline & & 91.62 & $237.96 \%$ & & 25.92 & $95.61 \%$ \\
\hline \multirow{3}{*}{ IV. } & \multirow{3}{*}{46.02} & 48.30 & $4.95 \%$ & \multirow{3}{*}{46.02} & 11.40 & $24.77 \%$ \\
\hline & & 74.04 & $60.89 \%$ & & 17.10 & $37.16 \%$ \\
\hline & & 66.24 & $43.94 \%$ & & 18.72 & $40.68 \%$ \\
\hline
\end{tabular}




\section{REFERENCES}

Dutko, P. (1957) Drevené konštrukcie pozemného stavitel’stva (Timber structures of civil engineering). Slovenská vysoká škola technická v Bratislave, Bratislava, Slovakia, 378 pp. [in Slovak].

Dutko, P. - Ferienčík, P. (1960) Drevené konštrukcie pozemného stavitel'stva (Timber structures of civil engineering). Slovenská vysoká škola technická v Bratislave, Bratislava, Slovakia, 465 pp. [in Slovak].

Dutko, P. - Ferienčík, P. (1961) Projektovanie novodobých drevených konštrukcií. Priklady I (Design of modern timber structures. Exercise I.). Slovenská vysoká škola technická v Bratislave, Bratislava, Slovakia, 402 pp. [in Slovak].

Dutko, P. - Lederer, F. - Ferienčík, P. - Čížek, L. (1976) Drevené konštrukcie (Timber structures). Alfa, Bratislava, Slovakia, 460 pp. [in Slovak].

Fairbairn W. (1859) Die eisernen Träger und ihre Anwendung beim Hochbau und Brückenbau. Verlag der Schulbuchhandlung.

Fejdin, A. (1988) Pevnost' a životnost' lepených spojov (Rigidity and durability of glued joints). Alfa, Bratislava, Slovakia. 288 pp. [in Slovak].

Gerner, M. (2003) Tesařské spoje (Carpentry joints). Grada Publishing a.s., Prague, Czech Republic, 220 pp., ISBN 80-247-0076-X [in Czech]

Hájek, V. (1997) Stavíme ze dřeva (Building from Timber). Sobotáles, Prague, Czech Republic, 156 pp., ISBN 80-85920-44-1 [in Czech]

Heinle, E. - Schlaich, J. (1996) Kuppeln aller Zeiten - aller Kulturen. Deutsche Verlags- Anstalt, pp 164-169.

Jeřábek, J. et al. (1954) Dřevěné konstrukce (Timber structures). Vysoká škola stavitelství v Brně, Brno, Czech Republic, 464 pp. [in Czech].
Kohout, J. - Tobek, A. (1996) Tesařství - tradice z pohledu dneš$k a$ (Carpentry - modern view of traditions). Grada Publishing a.s.., Prague, Czech Republic, 256 pp., ISBN 80-7169-413-4 [in Czech]

Koželouh, B. (1998) Dřevěné konstrukce podle Eurokódu 5, Step 1 (Timber constructions according to Eurocode 5, Step 1). Zlín, Czech Republic, 401 pp. ISBN 80-238-2620-4 [in Czech]

Koželouh, B. (2004) Dřevěné konstrukce podle Eurokódu 5, Step 1 (Timber constructions according to Eurocode 5, Step 2). Informační centrum ČKAIT. Prague, Czech Republic, 401 pp. ISBN 80-86 769-13-5 [in Czech]

Kuklík, P. (2005) Dřevěné konstrukce (Timber structures). Informační centrum ČKAIT. Prague, Czech Republic, 172 pp., ISBN 80-86769-72-0 [in Czech]

Kuklík, P. - Studnička, J. (2006) Dřevěné a kovové konstrukce (Timber and metal structures). Informatorium, Prague, Czech Republic, 187 pp., ISBN 80-7333-047-4 [in Czech]

Požgaj, A. - Chovanec, D. - Kurjatko, S. - Babiak, M. (1993) Struktúra a vlastnosti dreva (Structure and characteristics of timber). Príroda a.s., Bratislava, Slovakia, 485 pp., ISBN 80-0700600-1 [in Slovak]

Reinprecht, L. - Štefko, J. (2000) Dřevěné stropy a krovy (Timber ceilings and roofs). ABF a.s., Prague, Czech Republic, 242 pp., ISBN 80-86165-29-9 [in Czech]

Sandanus, J. - Sógel, K. (2010) Drevené nosné konštrukcie príkla$d y$ (Timber load-bearing systems - exercises). Slovak University of Technology in Bratislava, Bratislava, Slovakia, 126 pp., ISBN 978-80-227-3331-1 [in Slovak]

Tatarko, P. (2008) Ocel'ové a drevené konštrukcie I (Steel and timber structures I). Slovak University of Technology in Bratislava, Bratislava, Slovakia, 494 pp., ISBN 978-80-227-2924-6 [in Slovak] 